\title{
THE BLOOD-URINE UREA CONCENTRATION RATIO IN HYPERTENSION
}

By PAUL STARR, M.D. AND FRANCES BALLARD, B.S.

(From the Medical Department, Northwestern University Medical School and the Service of Dr. Charles A. Elliott at Wesley Memorial Hospital, Chicago)

(Received for publication August 5, 1927)

The blood-urine urea concentration ratio, following the work of MacLean (1), Harrison (2), Addis (3), Rabinowitch (4, 5, 6, 7) and Van Slyke $(8,9)$, has been determined in a series of 44 patients with vascular hypertension. They are arranged in three groups (tables 3, 4 and 5) of increasing severity of cardiovascular damage. They are not considered to have a primary nephritis; the extent of secondary renal damage was unknown.

\section{METHODS}

Following the plan of Rabinowitch, our procedure was as follows:

1. No food or fluids after 9:00 p.m.

2. Two grams of soda bicarbonate at 6:00, 7:00 and 8:00 p.m.

3. At 9:00 a.m.: (a) bladder emptied (specimen saved); (b) blood drawn; (c) phenolsulphonephthalein injected intravenously; (d) 15 grams of urea in 500 cc. of water by mouth (other workers use $150 \mathrm{cc}$. of water).

Urine collected at 10:00 and 11:00 a.m., 12:00 and 1:00 p.m. (no food or fluids during this period).

5. Blood drawn at 10:00 a.m. and 1:00 p.m.

The determinations made on these specimens are the volume and specific gravity, including the fasting specimen of urine, the phenolsulphonephthalein percentage and the concentration of urea in the urine of the second hour. This last is done by the usual aeration-nesslerization method. The blood urea nitrogen is determined in the three blood specimens by the new mercury titration method of Hench (10). The urea concentration factor is obtained by dividing the urea value in milligrams per $100 \mathrm{cc}$. of urine of the second hour by the average of the urea in milligrams per $100 \mathrm{cc}$. of blood in the fasting and first hour blood specimens. The reliability of the urease nesslerization technic used for the urine determination is well known. The observations of the English investigators would seem unreliable in view of the recognized faults in the hypobromite method which they use. The technical work is greatly shortened by employing 
TABLE 1

Urea nitrogen in milligrams per 100 cc. of blood

\begin{tabular}{c|c|c}
\hline Standard (Van Slyke technic) & Hench (titration technic) & Difference \\
\cline { 2 - 3 } 14.7 & $m g$. & $m g$. \\
13.5 & 16.0 & +1.3 \\
16.1 & 12.0 & -1.5 \\
20.4 & 14.0 & -2.1 \\
13.2 & 18.0 & -2.4 \\
14.8 & 14.0 & +0.8 \\
15.1 & 16.8 & +2.0 \\
17.1 & 14.8 & -0.3 \\
13.5 & 16.4 & -0.7 \\
11.1 & 11.2 & -2.3 \\
10.2 & 15.6 & +4.5 \\
13.9 & 14.2 & +4.0 \\
32.0 & 13.5 & -0.4 \\
26.4 & 28.0 & -4.0 \\
\hline Average difference....... & 22.4 & -4.0 \\
\hline
\end{tabular}

TABLE 2

Normal

\begin{tabular}{|c|c|c|c|c|c|}
\hline Name & 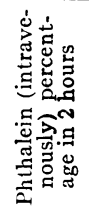 & 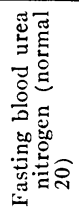 & 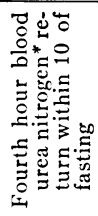 & 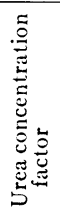 & Clinical diagnosis \\
\hline A. W. B... & 65 & 14 & 19 & 57 & Anemia \\
\hline J. G..... & 75 & 15 & 21 & 44 & Fracture \\
\hline B. McQ..... & 70 & 20 & 24 & 30 & Arthritis \\
\hline O. N......... & 55 & 11 & 17 & 33 & Hand injury \\
\hline O. N... & & 13 & 24 & 35 & Hand injury \\
\hline J. R........ & & $21 \dagger$ & 23 & 34 & Nerve injury \\
\hline F.S....... & 75 & 14 & 15 & 48 & Postoperative hernia \\
\hline R. W... & 60 & 23 & 25 & 25 & Hand injury \\
\hline Dr. H. . & 65 & 13 & 16 & 35 & Hand injury \\
\hline T. C... & 70 & 16 & 24 & 28 & Hand injury \\
\hline B. H....... & 65 & 13 & 23 & 47 & Neurosis \\
\hline R. B...... & 70 & 18 & 22 & 27 & Normal \\
\hline M. P. .... & 60 & 19 & 24 & 33 & Duodenal ulcer \\
\hline B. A... & 65 & 20 & 32 & 21 & Neurosis \\
\hline
\end{tabular}

* Following the work of Archer and Robb on urea tolerance.

$\dagger$ Emphasized figures are abnormal. 
the mercury titration method recently developed by Hench. He has published comparative results. Our series of comparisons is given in table 1 . The greatest difference is $4.5 \mathrm{mg}$. of urea nitrogen or $9.6 \mathrm{mg}$. of urea. (The average is 2.16 mg. of urea nitrogen or $4.6 \mathrm{mg}$. of urea.) This would usually make no serious change in the urea concentration factor as calculated but if the average error occurred in the same direction in both determinations, the false urea concentration factor would then be 2.5 points from the true value. Clinical estimations will certainly not require urea concentration factor of greater accuracy than this. In its present form the urea concentration factor range of error is probably 10 points owing to the unmeasured effect of diuresis.

\section{RESULTS}

In table 2 the data on 13 normal patients are given. The normal range of urea concentration factor by this procedure should thus be from 25 to 60 , rejecting the one reading 21 as being influenced by some diuretic factor.

In table 3 the data from the group of 22 patients with mild vascular disease are given. These patients are all active and have very slight disability. They carry systolic blood pressures of from 170 to $200 \mathrm{~mm}$. $\mathrm{Hg}$; the diastolic is in the neighborhood of $100 \mathrm{~mm}$. $\mathrm{Hg}$. There is more or less cardiac involvement. They do not have edema or unusual polyuria. There is little, if any, urinary evidence of nephritis. There is no gross evidence of heart failure in these patients. They are representative of that large group of people in whom hypertension is gradually leading to degenerative changes in the heart, brain, and kidneys, from which they will eventually die. It is in this type of case that it would be most valuable to be able to measure the extent of kidney damage and it is in this type of case that the usual renal tests are inadequate. Brief histories of two such patients follow:

Miss E. W., a school teacher, aged 68, active; only complaint severe and intractable hives. Physical examination: old goiter; infected tonsils; heart enlarged, left heart border $11 \mathrm{~cm}$; lungs negative; abdomen negative; no edema. Blood pressure 220/80; red blood cells 4,090,000; hemoglobin 47 per cent; urine entirely negative; basal metabolic rate -5 per cent; pulse 60 ; weight 130 ; positive Graham-Cole test; van den Bergh $0.2 \mathrm{mg}$.

Dr. L. F., aged 43, an active surgeon, admitted because of gall-stone colic. Later he was operated upon and returned to work. Physical examination: overweight; infected tonsils; lungs clear; no edema; heart enlarged, regular, no 
TABLE 3

Clinically mild vascular disease-slight or no cardiovascular symptoms; no evidence of heart failure; no gross edema; no isosthenuria

\begin{tabular}{|c|c|c|c|c|c|}
\hline Name & 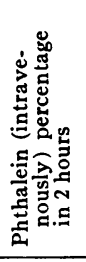 & 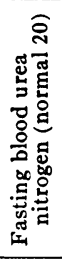 & 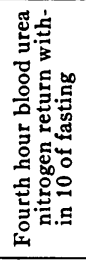 & 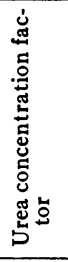 & Clinical diagnosis \\
\hline J. C. & 65 & 13 & 15 & 63 & $\begin{array}{l}\text { Essential hypertension; age } 22 \text {; blood } \\
\text { pressure } 185 / 110\end{array}$ \\
\hline M. R. & 65 & 26 & 32 & 28 & $\begin{array}{l}\text { No symptoms; age } 26 \text {; blood pres- } \\
\text { sure } 150 / 90\end{array}$ \\
\hline F. H. & 25 & 18 & 26 & 33 & $\begin{array}{l}\text { Slight symptoms; age } 24 \text {; blood } \\
\text { pressure } 170 / 90\end{array}$ \\
\hline F. B. E. & & 14 & 27 & 29 & $\begin{array}{l}\text { Mild arteriosclerosis; blood pressure } \\
168 / 110\end{array}$ \\
\hline G. F. & 50 & 13 & 22 & 22 & $\begin{array}{l}\text { Obesity; arthritis; blood pressure } \\
200 / 110\end{array}$ \\
\hline L. F. & 60 & 15 & 18 & 39 & $\begin{array}{l}\text { Cholecystitis; blood pressure } \\
190 / 118\end{array}$ \\
\hline G. I. & 55 & 21 & 27 & 32 & Uterine tear; blood pressure $170 / 98$ \\
\hline M. M & 20 & 16 & 31 & 43 & $\begin{array}{l}\text { Hypertension; blood pressure } \\
200 / 110\end{array}$ \\
\hline $\mathrm{S}$. & 60 & 24 & 37 & 22 & Iritis; blood pressure $180 / 108$ \\
\hline R. B. & 50 & 19 & & 24 & $\begin{array}{l}\text { Puerperal headaches; blood pressure } \\
178 / 110\end{array}$ \\
\hline S. R. . & 50 & 15 & 21 & 26 & Headaches; blood pressure $194 / 112$ \\
\hline J. S & 60 & 21 & 23 & 32 & $\begin{array}{l}\text { Senility; prostatic obstruction; blood } \\
\text { pressure } 196 / 90\end{array}$ \\
\hline H. B.. & 60 & 26 & 35 & 32 & $\begin{array}{l}\text { Weakness; anemia; blood pressure } \\
200 / 98\end{array}$ \\
\hline L. $\mathrm{S}$ & 60 & 23 & 32 & 24 & $\begin{array}{l}\text { Melancholia; hypertension; blood } \\
\text { pressure 218/124 }\end{array}$ \\
\hline E. V & 75 & 22 & 35 & 15 & $\begin{array}{l}\text { Hives; cardiac hypertrophy; blood } \\
\text { pressure } 200 / 80\end{array}$ \\
\hline C. $\mathrm{L}$ & 65 & 26 & 56 & 13 & Arthritis; blood pressure $196 / 110$ \\
\hline J. J. & 60 & 16 & 28 & 22 & $\begin{array}{l}\text { No symptoms; blood pressure } \\
200 / 110\end{array}$ \\
\hline R. W. I & & 14 & 28 & 33 & $\begin{array}{l}\text { No symptoms; blood pressure } \\
190 / 98: 158 / 80\end{array}$ \\
\hline S. $\dot{R}$. & 55 & 21 & 27 & 27 & $\begin{array}{l}\text { Effort syndrome; blood pressure } \\
184 / 100\end{array}$ \\
\hline E.W. & 45 & 22 & 28 & 30 & Tired; hives; blood pressure 198/110 \\
\hline E. D.. & 40 & 19 & & 11 & $\begin{array}{l}\text { Tired; cholecystitis; blood pressure } \\
200 / 100\end{array}$ \\
\hline M. F. & 45 & 19 & 26 & 27 & $\begin{array}{l}\text { Arteriosclerosis; glycosuria; blood } \\
\text { pressure } 155 / 68\end{array}$ \\
\hline
\end{tabular}


murmurs; gall-bladder tenderness. Blood pressure 220/130; later 188/118 and $160 / 110$; urine contained slight trace of albumin, no casts; red blood cells 4,240,000;

TABLE 4

Severe vascular disease-marked cardiovascular symptoms; no gross edema except for one case with heart failure; no isosthenuria

\begin{tabular}{|c|c|c|c|c|c|}
\hline Name & 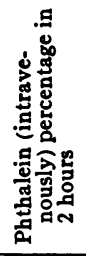 & 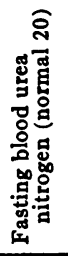 & 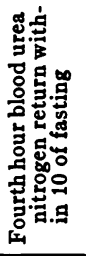 & 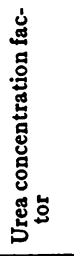 & Clinical diagnosis \\
\hline T. L. A. . & 65 & 12 & 28 & 27 & $\begin{array}{l}\text { Angina; senility: blood pressure } \\
218 / 96 \text {; died-cerebral hemor- } \\
\text { rhage }\end{array}$ \\
\hline C. L. H. . & 60 & 9 & 12 & 14 & $\begin{array}{l}\text { Coronary thrombosis; blood pressure } \\
100 / 60\end{array}$ \\
\hline S. L. & 30 & 17 & 34 & 29 & Heart failure; blood pressure $154 / 110$ \\
\hline A. von $\mathrm{H}$ & 70 & 22 & 29 & 25 & $\begin{array}{l}\text { Arteriosclerosis; heart block; blood } \\
\text { pressure } 182 / 86\end{array}$ \\
\hline S. W.. & 55 & 16 & 24 & 17 & Angina; blood pressure $220 / 120$ \\
\hline C. M. G & 60 & 23 & 34 & 8 & $\begin{array}{l}\text { Uremic headache; nocturia; blood } \\
\text { pressure } 180 / 105\end{array}$ \\
\hline L. $\mathrm{H}$ & 50 & 22 & 34 & 21 & $\begin{array}{l}\text { Auricular fibrillation; blood pressure } \\
240 / 140\end{array}$ \\
\hline L. $\mathrm{H}$ & 40 & 48 & 67 & 16 & $\begin{array}{l}\text { Hemiplegia; blood pressure 238/132; } \\
\text { death }\end{array}$ \\
\hline H. R & 50 & 26 & 28 & 21 & $\begin{array}{l}\text { Angina; vertigo: blood pressure } \\
\text { 180/110; died suddenly }\end{array}$ \\
\hline M. R... & 45 & 18 & 28 & 16 & $\begin{array}{l}\text { Cerebral thrombosis; blood pressure } \\
204 / 120\end{array}$ \\
\hline H. B. . & 60 & 26 & 33 & 13 & $\begin{array}{l}\text { Hypertension; dyspnea; headaches; } \\
\text { blood pressure } 210 / 120\end{array}$ \\
\hline J. B. & 45 & 28 & 40 & 27 & $\begin{array}{l}\text { Arteriosclerosis; cerebral thrombosis; } \\
\text { blood pressure } 150 / 80\end{array}$ \\
\hline J. A. & 65 & 24 & 29 & 24 & $\begin{array}{l}\text { Hypertension; gallop rhythm; blood } \\
\text { pressure } 170 / 120\end{array}$ \\
\hline T. G. E & 35 & 26 & 34 & 19 & $\begin{array}{l}\text { Retinitis; gallop rhythm; blood } \\
\text { pressure } 200 / 130\end{array}$ \\
\hline I. N. V & 35 & 28 & 45 & 16 & $\begin{array}{l}\text { Hypertension with nephritis with } \\
\text { edema; blood pressure } 270 / 158\end{array}$ \\
\hline
\end{tabular}

white blood cells 6,400; hemoglobin 80 per cent; Wassermann test negative; stools normal; electrocardiogram normal; van den Bergh $2.9 \mathrm{mg}$. 
The phenolsulphonephthalein results in this series are all high normal with the exception of five. The fasting blood urea nitrogen is often very slightly elevated but not sufficiently to indicate definite azotemia. Of the twenty-two there are 13 urea concentration fac-

TABLE 5

Extreme vascular disease

\begin{tabular}{|c|c|c|c|c|c|c|}
\hline Name & 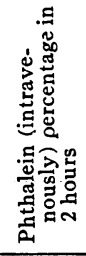 & 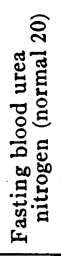 & 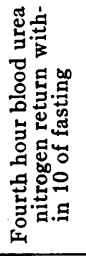 & 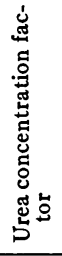 & 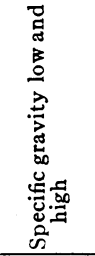 & Clinical diagnosis \\
\hline $\mathrm{F}$ & 60 & 12 & 19 & 28 & $\begin{array}{l}1.008 \\
1.017\end{array}$ & $\begin{array}{l}\text { Malignant hypertension; reti- } \\
\text { nitis; age } 32 \text {; blood pressure } \\
222 / 158\end{array}$ \\
\hline I. A. & 55 & 11 & 21 & 14 & $\begin{array}{l}1.009 \\
1.030\end{array}$ & $\begin{array}{l}\text { Malignant hypertension; cere- } \\
\text { bral hemorrhage: age } 34 \text {; } \\
\text { blood pressure } 220 / 120\end{array}$ \\
\hline M. D. & 60 & 16 & 15 & 18 & $\begin{array}{l}1.008 \\
1.022\end{array}$ & $\begin{array}{l}\text { Malignant hypertension; an- } \\
\text { gina; age } 35 \text {; blood pressure } \\
260 / 150\end{array}$ \\
\hline A. L. & 40 & 20 & 21 & 18 & $\begin{array}{l}1.015 \\
1.020\end{array}$ & $\begin{array}{l}\text { Hypertension; cardiac decom- } \\
\text { pensation; blood pressure } \\
220 / 120\end{array}$ \\
\hline
\end{tabular}

Fixation of specific gravity

\begin{tabular}{|c|c|c|c|c|c|c|}
\hline N. L. & 15 & 65 & 81 & 9 & $\begin{array}{l}1.008 \\
1.010\end{array}$ & $\begin{array}{l}\text { Final stage nephritis; decom- } \\
\text { pensation; blood pressure } \\
228 / 140 \text {; death }\end{array}$ \\
\hline R. P. & 30 & 32 & 35 & 3 & $\begin{array}{l}1.007 \\
1.010\end{array}$ & $\begin{array}{l}\text { Final stage nephritis; edema; } \\
\text { blood pressure 184/130; } \\
\text { death }\end{array}$ \\
\hline E. LaT. & 20 & 36 & 53 & 7 & $\begin{array}{l}1.007 \\
1.010\end{array}$ & $\begin{array}{l}\text { Malignant hypertension; blood } \\
\text { pressure } 270 / 140 \text {; death }\end{array}$ \\
\hline C. R. E. & 10 & 42 & 46 & 12 & $\begin{array}{l}1.010 \\
1.010\end{array}$ & $\begin{array}{l}\text { Malignant hypertension; blood } \\
\text { pressure 200/120; death }\end{array}$ \\
\hline
\end{tabular}

tors below 30; of these, 8 are definitely abnormal, i.e., below 25 . Two are below 20 .

In table 4 the data on 14 patients with severe vascular disease are shown. In these patients the systolic blood pressure is frequently 
over 200, the diastolic frequently over 110 . The extent of vascular damage is evidenced by angina, coronary thrombosis, heart block, auricular fibrillation, cerebral thrombosis, and headache. There is one case with cardiac decompensation. Brief histories of two such patients follow:

Mr. O., aged 57, gradual onset of right hemiplegia with associated aphasia. Physical examination: lungs clear; heart-left hypertrophy, regular; right arm and leg partially paralyzed; $n$ edema; vessels of fundi sclerotic. Blood pressure 204/120, later 192/106; urine contains trace of albumin, occasional granular cast.

Mrs. W., aged 60. Dull aching in left chest during exertion, stops immediately on resting, no dyspnea, no edema. Physical examination: lungs normal; heartconcentric hypertrophy; abdomen normal; pelvis normal. Blood pressure

TABLE 6

Nephritis without hypertension

\begin{tabular}{|c|c|c|c|c|c|}
\hline Name & 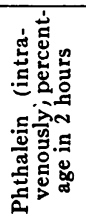 & 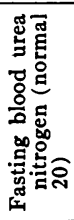 & 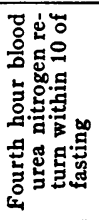 & 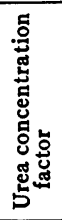 & Clinical diagnosis \\
\hline K. K. & 55 & 20 & 40 & 25 & $\begin{array}{l}\text { Acute parenchymatous ne- } \\
\text { phritis; blood pressure } 125 / 85\end{array}$ \\
\hline M. K. & 45 & 25 & 33 & 15 & $\begin{array}{l}\text { Cystitis; syphilis; blood pressure } \\
118 / 68\end{array}$ \\
\hline E. P.... & $\mathbf{0}$ & 157 & 191 & 7 & $\begin{array}{l}\text { Hydronephrosis (bilateral); iso- } \\
\text { sthenuria; blood pressure } \\
124 / 78 \text {; death }\end{array}$ \\
\hline
\end{tabular}

$218 / 118,222 / 120$. Urine negative; basal metabolic rate -5 per cent; blood urea nitrogen 19.6; red blood cells 4,210,000; white blood cells 6,700; hemoglobin 86 per cent; Wassermann test negative.

Of the fourteen cases only three have phenolsulphonephthalein results of clinical significance. These are 30,35 , and 35 per cent. In six cases the urine contains little albumin; in the others it contains much albumin and some casts. There is no correspondence between the phthalein percentage, the urea concentration factor and the amount of albumin. In nine there is a slight increase of the fasting; blood urea nitrogen. In all fourteen the urea concentration factor 
is less than 30 and in ten it is less than 25; of these it is less than 20 in seven cases.

In table 5 the results from a series of patients with extreme hypertension are given. One early case in a young man and one case in the terminal stage are described.

TABLE 7

Correlation of change of urea concentration factor to volume

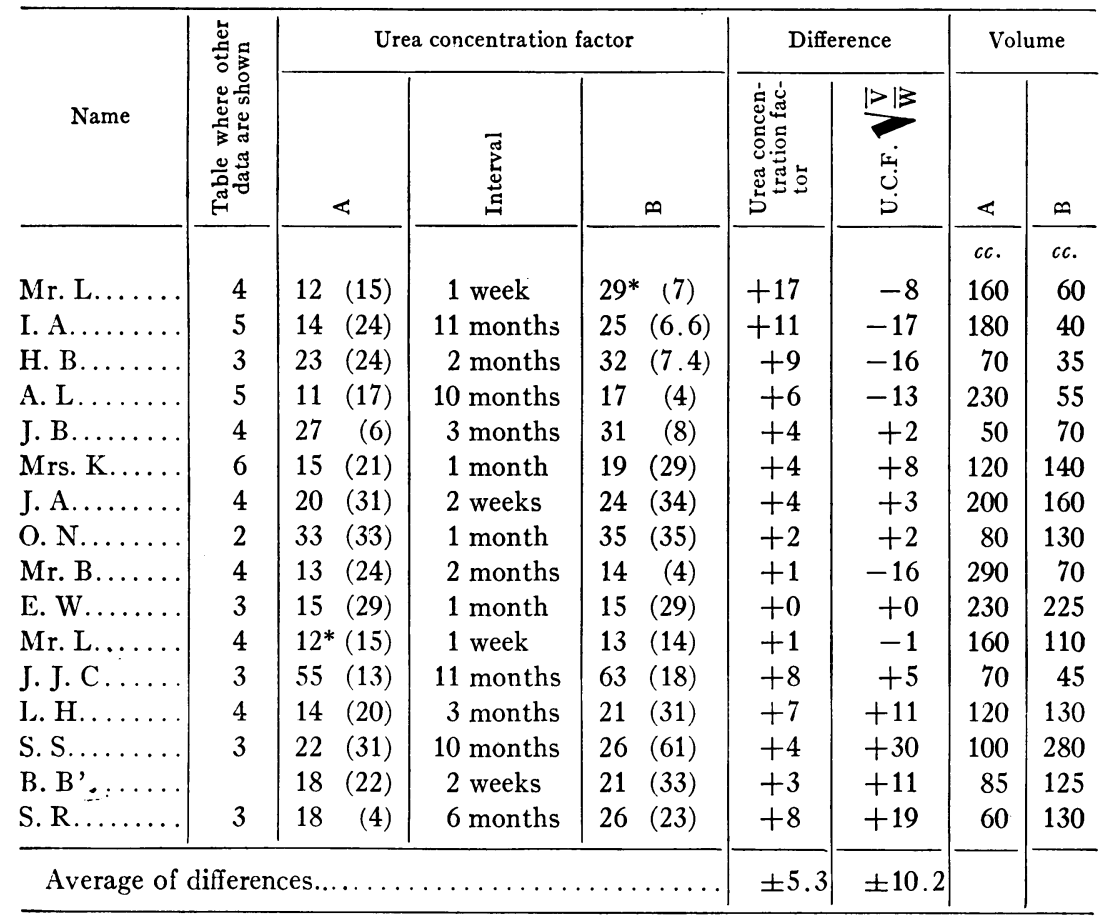

Figures in parenthesis $=$ Our U.C.F. $\times \sqrt{\text { Volume given } \div \text { Weight in kilograms. }}$

* During acute decompensation urea concentration factor 29; when improved 1 week later urea concentration factor 12; third urea concentration factor still later 13.

Dr. J. F., aged 32, a dentist, was known to have had gradually increasing hypertension for six years; at first very mild, later extreme. Complained of headaches and nervousness; later, visual disturbance. Physical examination: lungs clear; heart enlarged, aortic second accentuated; abdomen and extremities normal, no edema. Blood pressure 226/160; urine-albumin ++ and +++ , occasional granular cast; red blood cells 4,200,000; white blood cells 9,100; hemoglobin 90 per cent, spinal fluid and blood Wassermann negative. Fundi showed albuminuric retinitis. 
Mr. LaT., aged 50, high blood pressure known for nine years. Complained of no pain or inability to continue his work as usual; no nocturia; slight edema of ankles. Lungs clear; heart much enlarged. Blood pressure 270/140 and 295/170; urine-albumin ++ , occasional granular cast, fixed specific gravity; Wassermann test negative.

Of the eight cases five have definitely depressed phthalein readings. In those cases with renal insufficiency, as indicated by azotemia, there is definite isosthenuria. In this whole group the urea concentration factor is less than 30 and all but one are below 20; three are 10. It is interesting to note that those patients whose urea concentration factor was approximately 10 or below have died.

In table 6 the data of three patients having nephritis without hypertension are given. A correspondence with the clinical severity is evident.

In contrast, however, with this general parallelism with the degree of vascular disease there are occasions when very low figures are obtained which certainly do not represent the clinical condition. Thus, the specific gravity of the urine may be low and the urea concentration in the neighborhood of a few tenths of a per cent, while the blood figure is not unusual; the result is a very low factor. This happened definitely three times in a total of eighty-three urea concentration factor determinations but it is probable that the factor is often several points too low as judged by clinical criteria. Furthermore, as regards prognosis serious vascular accidents may, of course, occur with relatively good kidney function as indicated by this factor.

To determine the constancy with which this crude procedure would give checks it was repeated whenever possible. Table 7 presents 17 duplicates. In most instances the checks are remarkably good. The greatest differences, 11 and 17, are probably due to a change in circulation. Other differences may well correspond to an actual change in renal function. The average difference, including the two factors distorted by gross circulatory disturbances is plus or minus five. Even with this range of error the results are of clinical value in helping to grade the renal damage in patients with vascular hypertension into, roughly, three divisions, mild or negligible, moderate, and severe.

In table 7 a correlation between the change of urea concentration 
factor and the change of volume in these successive tests is presented. Concerning these seventeen duplicates, inspection of the table indicates that where the second volume increased, as was true in six instances, the urea concentration factor also increased, i.e., contrary to what would be expected from simple dilution of the urine. When the volume decreased, as was true in eight, including the instance before and after decompensation, the urea concentration factor increased on an average eight points. Hence, no constant influence of change of volume is found. A check of successive urea concentration factors to four points or less occurs in nine instances. In these the changes in volume are from 70 to $290 \mathrm{cc}$., from 100 to 280 cc., from 200 to $160 \mathrm{cc}$., from 80 to 130 cc., from 230 to 225 cc., from 160 to $110 \mathrm{cc}$., from 120 to $130 \mathrm{cc}$., from 50 to $70 \mathrm{cc}$., and from 85 to $125 \mathrm{cc}$. Thus a very marked change in volume may not significantly change the urea concentration factor. It would, therefore, seem incorrect to uniformly modify the urea concentration factor by the volume. When our factor is multiplied by the square root of the quotient volume over weight of the patient in kilograms, the correspondence between the resulting modified factors is much less close than when the simple urea concentration factor is used and they would frequently indicate a change in renal condition which the clinical findings do not support and which the simple factors do not suggest. Modified factors, $U C F \times \sqrt{\frac{V}{W}}$, are shown in parentheses after each simple factor in table 7 .

\section{CONCLUSION}

This procedure for measuring the ability of the kidney to concentrate urea is of clinical value. It seems possible by this means roughly to estimate that the degree of renal damage in hypertension is either negligible, moderate, or severe. A method of controlling the influence of water metabolism and excretion on the final result would very much increase the quantitative significance of the test.

\section{BIBLIOGRAPHY}

1. MacLean, H., and deWesselow, O. L. V., Quart. J. Med., 1919, xii, 347. An Investigation into the Effects of War Nephritis on Kidney Function, with Observations on Methods for Estimating the Efficiency of the Kidneys. 
2. Harrison, G. A., Brit. J. Exp. Path., 1922, iii, 28. On Urea Tests of Renal Function.

3. Addis, T., Myers, B. A., and Oliver, Jean, Arch. Int. Med., 1924, xxxiv, 243. The Regulation of Renal Activity. IX. The Effect of Unilateral Nephrectomy on the Function and Structure of the Remaining Kidney. Addis, T., and Foster, Marjorie G., Arch. Int. Med., 1924, xxxiv, 462. The Concentrating Capacity of the Kidney.

4. Rabinowitch, J. M., Arch. Int. Med., 1921, xxviii, 827. A Study of the Urea Concentration Test for Kidney Function.

5. Rabinowitch, I. M., Arch. Int. Med., 1923, xxxii, 927. The Urea Concentration Factor in the Estimation of Renal Efficiency.

6. Rabinowitch, I. M., Arch. Int. Med., 1924, xxxiv, 365. A Quantitative Index of Kidney Function. Thermodynamic Considerations in the Estimation of Renal Efficiency.

7. Rabinowitch, I. M., Jour. Biol. Chem., 1925, lxv, 617. Urea Test of Renal Efficiency. I.

8. Van Slyke, D. D., Linder, G. C., Hiller, Alma, Leiter, L., and McIntosh, J. F., Jour. Clin. Invest., 1926, ii, 255. The Excretion of Ammonia and Titratable Acid in Nephritis.

9. Austin, J. H., Stillman, E., and Van Slyke, D. D., Jour. Biol. Chem., 1921, xlvi, 91. Factors Governing the Excretion Rate of Urea.

10. Hench, P. S., and Aldrich, M., Arch. Int. Med., 1926, xxxviii, 474. Urea Retention: A Simple Method for its Estimation by the Mercury Combining Power of Blood. 